\title{
Substitution schreibt Erfolgsgeschichten
}

Für ein Engagement der Hausärzte in der Substitutionsmedizin machte sich ein Experte in MMW 16/2015, S. 69, stark. Die Behandlung

Suchtkranker sei sinnvoll und erfüllend. Ein Leser sieht das ähnlich:
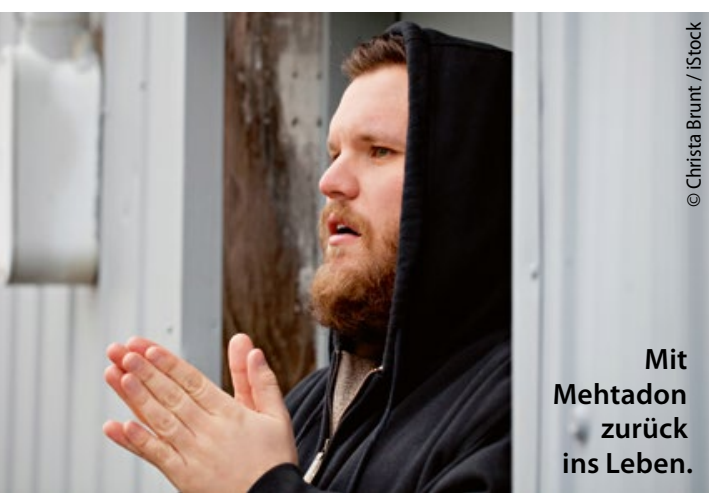

Seit 20 Jahren substituiere ich ca. 50 Patienten im Quartal. Die Maximaldosis - Ausnahmen gibt es immer - liegt bei $8 \mathrm{ml} / \mathrm{d}$ Methadon oder $8 \mathrm{mg} / \mathrm{d}$ Buprenorphin. Hier drei Beispiele:

1. Eine junge Frau erhält $0,3(!) \mathrm{ml} \mathrm{Me}-$ thadon. Das ist schon fast homöopathisch, sie hat aber Angst vor einer weiteren Reduzierung. Nach Rücksprache mit der Apotheke wird nach und nach verdünnt, und die Patientin erhält für ca. fünf Wochen nur noch
Wasser, ohne es zu merken. Als ich es ihr dann sage, ist sie glücklich.

2. Ein kräftiger Mann $(185 \mathrm{~cm}, 82 \mathrm{~kg})$ erhält $12 \mathrm{ml}$ Methadon pro Tag. Nach ca. drei Jahren Substitution hört er ohne Entzugserscheinungen auf.

3. In einer psychiatrischen Klinik erhält ein Patient $42 \mathrm{ml}$ Methadon pro Tag. Ich habe es schriftlich!

80.000 Menschen sterben in Deutschland im Jahr durch Alkohol, 120.000 an den Folgen des aktiven Rauchens, 220.000 durch Adipositas. Ihnen einen schwachen Willen zu unterstellen, ist verpönt. Da zeigt man lieber auf die 800-900 Drogentoten im Jahr.

- Dr. Hartmut Heinlein, Ringstr. 10, D-37632 Eschershausen

\section{Hier steht eine Anzeige.}

望 Springer 